\title{
Fitting the Facts and Capitalizing on New Opportunities to Redesign Rural Development Programs in Latin America*
}

Alain de Janvry and Elisabeth Sadoulet ${ }^{1}$

\section{Slippage between institutions and objective conditions for rural development}

In a world of rapidly changing economic opportunities, institutions frequently lag relative to the objective conditions over which they apply, creating dysfunctionalities that can have high social costs. The Indian caste system is a classical example of such institutional slippage between division of labor and social class positions, with not only high welfare costs for members of lower castes but also high overall efficiency costs. Such dysfunctionalities can also characterize policies and programs. Approaches to rural development pursued by national governments and international development agencies tend to be among them. Most rural development programs currently in place have not adjusted to the new realities of the context where they apply.

Lack of adjustment of institutions to changes in objective conditions can come from a variety of causes (Akerlof, 1984). They include most frequently imperfect information about emerging realities, path dependency due to high sunken costs in the current institution, coordination failures in achieving a switch among multiple institutional equilibria,

*Trabalho apresentado pelo Professor Alain de Janvry no XLII Congresso Brasileiro de Economia e Sociologia Rural, Cuiabá, MT, em 25/07/2005.

${ }^{1}$ University of California at Berkeley 
- Fitting the Facts and Capitalizing on New Opportunities to Redesign Rural Development Programs in Latin America

and social opposition to change by losers when there is no credible commitment device to guarantee that they will be compensated by gainers, even though net social gains will be realized.

Programs addressing rural poverty tend to suffer from this defect. This can be for several of the causes of dysfunctionalities mentioned above. Most benign, but first in need to be overcome, is imperfect information: rapid changes in the qualitative nature of poverty may remain unnoticed. With imperfect information, programs are perpetuated based on concepts of poverty that no longer correspond to reality. In addition, program adjustments are costly due to high sunken costs in the old approach, postponing investment in alternative designs that require new expertise and new administrative set-ups. Dysfunctionalities in rural poverty reduction programs pursued by national governments and international development agencies are visible through the following typical aspects of these initiatives:

- They tend to dissociate social from productive investments, and have been more successful with the former than with the latter in benefiting the rural poor.

- They have given extensive support to local development through municipal decentralization and community-driven development (CDD) programs which have proven to be effective for investments in local public goods (mainly small scale infrastructure and basic social services), but are weak for the generation of new income opportunities, and hence for poverty reduction. ${ }^{2}$

- They mainly focus on agriculture as an approach to rural poverty reduction and are administered sectorally for support to productive investments. Few projects are in support of local economic development with an integral focus on all activities that enter in the sources of income of the region and its people.

- They focus more on increasing the asset endowments of the poor (which is a necessary condition for escaping poverty), than in improving the opportunities the poor have in using the assets they

${ }^{2}$ According to Mansuri and Rao (2003), World Bank funding of CDD programs has increased from \$325 million in 1996 to \$2 billion in 2003. 
control to move out of poverty. Emphasis has thus been given to assets with insufficient concern for the quality of the context where the assets are used.

The result has been a general improvement in the social conditions of the poor (particularly health, education, nutrition, housing, infrastructure, and old age pensions), but steady reproduction of poverty, inequality, and vulnerability in rural Latin America. Migration has been the great escape valve from rural poverty, as opposed to rising rural incomes. This is because, while the determinants of poverty have changed, and the set of opportunities to escape poverty have also been redefined, rural development programs and policies still basically follow an approach that no longer fits the facts. This is true for the determinants of income more than for social development. As a consequence, there has been more progress in the latter than in the former.

We argue in this paper that the qualitative nature of rural poverty has changed markedly in the last decade, and that the set of opportunities in redefining approaches to rural development has also been transformed. While this has been discussed by a number of experts in the field, a complete interpretation of this phenomenon seems to be still lacking. Remarkable new ideas and experiments exist piecemeal, but they have not been incorporated in the approaches to raising rural incomes pursued by governments and international development agencies at a sufficient scale to make a difference. Perhaps fault lies with social scientists who have not made the case sufficiently clearly about (1) recent changes in the qualitative nature of poverty, (2) existence of new opportunities to address rural poverty, and (3) design of, experimentation with, and impact analysis of new approaches to rural development that "fit the facts" and "capitalize on new opportunities".

In what follows, we address these three issues. We first briefly recap recent evolution with the quantitative nature of poverty in order to evidence lack of progress. We then go over an assessment of recent qualitative changes in the nature of rural poverty. This is followed by an identification of new opportunities to address rural poverty. We then apply this information to an outline of how to approach rural poverty in a way that better fits the facts and capitalizes on opportunities. This 
- Fitting the Facts and Capitalizing on New Opportunities to Redesign Rural Development Programs in Latin America

is illustrated using available case studies of new approaches to regional and rural development.

The approach we suggest to reconcile rural development programs with facts and opportunities builds upon a number of recent contributions to the analysis of a territorial approach to rural development, that articulates rural and urban growth dynamics into an integral regional approach, complemented by a strategy to incorporate the rural poor to the opportunities created by regional growth. Some of the main architects of the approach on whose work we draw are Alejandro Schejtman and Julio Berdegué (2003), Ricardo Abramovay (1999, 2003), Ruben Echeverria (2004), Llorens, Albuquerque, and del Castillo (2002), and Rafael Echeverri (2000).

\section{Quantitative evolution of rural poverty}

There are five sets of indicators that give us the basis for discontent with current approaches to rural development. We evidence each of them briefly with available data.

\section{The incidence of rural poverty has generally not declined and the number of rural poor has increased.}

The quality of poverty measurements remains deplorable. Because of this, available evidence is incomplete and often contradictory. Overall, available evidence basically shows a flat profile in the incidence of rural poverty between 1970 and 2000. For Latin America as a whole, the incidence of extreme poverty has remained $28 \%$ over the last 30 years. In Mexico, the incidence of rural poverty has remained in the 45 to $50 \%$ range since 1970 . In Brazil, CEPAL data suggest a decline in the incidence of poverty between 1986 and 1996, while World Bank data show no decline (Wodon, 2000). With stagnant poverty incidence, the number of rural poor has increased.

\section{Rural inequality is exceptionally high and increasing}

High inequality is a well known specificity of Latin American societies. 
What is also specific to Latin America is that local inequalities tend to be as high as national inequalities. This is seen in poverty maps that decompose total inequality into within and between locality effects. For rural communities in Ecuador, $86 \%$ of total inequality is explained by within-community (parroquias) inequality and only $14 \%$ by between community inequality (Elbers, Lanjouw, Mistiaen, Özler, and Simler, 2004). Inequality is thus a pervasive feature that is present even at the local level. High local inequalities imply that local growth will have little value for poverty reduction. What further is that rural inequality has been increasing, even when it may be decreasing in the urban sector. To be effective, any poverty reduction strategy at the local level must consequently address the issue of inequality, and identify the mechanisms through which local inequalities are being reproduced over the long term. Linking anti-poverty strategies to inequality reduction puts rural development initiatives in a new perspective, different from traditional approaches to rural development that have been concerned with the incomes of the poor.

With the exception of Colombia and Central America, rising inequalities have been the norm in all other countries. In Mexico, the rural Gini rose from 0.46 in 1992-94 to 0.51 in 2000-02 while the urban Gini fell from 0.50 to 0.47 over the same period. There is also evidence that inequalities tend to rise sharply during recessions, and may fail to fall during periods of recovery (de Janvry and Sadoulet, 2000). Concern with inequality should thus pay particular attention to sheltering not only the poor but also the middle class during periods of economic downturn. In these periods, the "new poor" tend to come from these sectors, contributing to rising inequalities. Combating rural poverty thus requires concern with two complementary fronts: combating economic instability and combating inequality.

\section{Social development has improved, even though gaps between rural and urban social development remain large}

There has been remarkable progress with social development, particularly education and health for the poorest. Indeed, while Latin America is failing to meet the Millennium Development Goals in poverty 
- Fitting the Facts and Capitalizing on New Opportunities to Redesign Rural Development Programs in Latin America

reduction, it is on target to meet the goals in primary school enrollment and child mortality. In Mexico, there has been a rapid rise in secondary and higher education, even though levels remain very low, rising from $11.5 \%$ in 1992 to $21.3 \%$ in 2002 . In Colombia, illiteracy rates have been halved between 1978 and 1999 and school enrollment has increased by $37 \%$ in primary school and $52 \%$ in secondary school. Health indicators have all improved. In Honduras, between 1980 and 1997, vaccination rates have increased by $90 \%$, births in hospitals by $43 \%$, and population with access to water and sanitation by $60 \%$.

Access to basic infrastructure services has also improved. In Mexico, poor households with access to electricity increased from $88 \%$ to $98 \%$ between 1992 and 2002. For access to water services, gains were from 65 to $86 \%$, for hard floors from 79 to $91 \%$, and for sewage from 53 to $69 \%$. While rural standards remain inferior to urban standards and uneven across rural regions, catching up has been remarkable.

Asymmetry between income gains, with rural poverty remaining "broad and deep", and social development that has progressed is thus a hallmark of Latin American rural development. The challenge for rural development is thus to achieve gains in income to keep at par with the gains achieved in social development.

\section{Urban migration has been the great escape valve in preventing a larger increase in rural poverty. Poverty has been displaced toward the urban environment}

The number of urban poor has increased faster than the number of rural poor. In calculations we did using the CEPAL data, we showed that most of the relative decline in the share of the rural population in total poverty has not been due to declining incidence of poverty in rural areas, but to population shifts between rural and urban sectors (de Janvry and Sadoulet, 2000). Migration has thus been the main contributor to displacement of poverty from rural to urban areas. The share of urban population growth due to internal migration and relocation was $40 \%$ in the 1960 s, $41 \%$ in the 1970 s, and $34 \%$ in the 1980 s (Katz, 2004). The missing task for rural development is consequently to help retain populations in rural regions (but not in agriculture where structural changes 
imply the need for falling employment), while reducing the incidence of poverty among rural populations.

\section{Qualitative changes in rural poverty}

There are deep changes in the qualitative nature of rural poverty. Most important for the redesign of rural development are the following eight:

\section{There is increasing differentiation between two locations for rural poverty: MRA (marginal rural areas) and FRA (favorable rural areas)}

Part of the rural poor is geographically concentrated in low population density MRA (marginal rural areas) defined as areas with either poor agro-ecological endowment and/or isolated from access to markets and employment centers. They consist in:

- Geographical pockets of poverty: Mexico's Southern States, Brazil Northeast, Central America's East Coast regions, and high altitudes in the Altiplano.

- Indigenous territories: Indigenous communities attached to their homelands in the Altiplano and the East Coast of Central America.

- These geographically concentrated poor are largely not benefited by national economic growth.

The other part of the rural poor is socially diffused in FRA (favorable rural areas) defined as areas with good agro-ecologies and good connections to dynamic product and/or labor markets. They consist in:

- Individuals with low asset endowments, especially land, education, and social capital.

- Individuals with asset endowments, but lacking opportunities to valorize these assets in the territories where they are located (lack of regional dynamics).

- Rural youth and elderly people for whom social assistance programs are needed. 
Work with GIS information and poverty mapping is important to establish this territorial dimension of rural development. In Nicaragua, for instance, half of the extreme poor live in the quarter of the country that is within four hours travel time to Managua (Raine et al., 2004). In these regions, which are well endowed agro-ecologically and well connected to markets and employment centers, poverty is socially diffused. Even though they offer the greatest employment and investment opportunities, poor households are those with low asset endowments (especially education, land, and social capital) and consequently low capacity to take advantage of these opportunities. The rest of rural poverty in Nicaragua is concentrated in MRAs with unfavorable agro-ecological endowments, lack of access to markets and employment centers, and frequently composed of indigenous communities in ancestral territories.

\section{There are major changes in the structure of employment and sourc es of income for rural populations}

Reliance on non-agricultural employment and income for the rural population has been increasing rapidly and is of great importance.

\subsection{Changes in employment patterns}

Farm employment has declined in most countries, especially its selfemployment component. There has by contrast been a rapid rise in the share of rural population employed in non-agricultural wage labor and non-agricultural self-employment. For men, Durston et al. (2000) give the following changes in percentage employed in non-farm activities:

$\begin{array}{lllll}\text { Chile } & 19 \% & (1990) & 26 \% & (1998) \\ \text { Colombia } & 31 \% & (1991) & 33 \% & (1997) \\ \text { Costa Rica } & 48 \% & (1990) & 57 \% & (1997) \\ \text { Honduras } & 19 \% & (1990) & 22 \% & (1998) \\ \text { Mexico } & 35 \% & (1989) & 45 \% & (1996) \\ \text { Panama } & 25 \% & (1989) & 47 \% & (1998) \\ \text { Venezuela } & 34 \% & (1990) & 35 \% & (1994) \\ \text { Brazil } & 26 \% & (1990) & 24 \% & (1997)\end{array}$


With the exception of Brazil, these figures show that employment in non-farm activities of the rural employed population has been rising rapidly. For Brazil, other sources show a clear increase in rural nonfarm employment. Between 1981 and 1997, rural non-farm employment increased by $95 \%$ in the Northeast, $51 \%$ in Sao Paulo, $52 \%$ in the Southeast, $69 \%$ in the South, and $100 \%$ in the center-West.

\subsection{Changes in sources of income}

Corresponding to changes in employment patterns, there have been rapid changes in sources of income, with addition of a rapid rise in transfers, particularly remittances from migrants. For Mexico (World Bank-Mexico, 2004), changes in sources of income for the rural population have been as follows between 1992 and 2002:

Independent farming

Agriculture wage labor

Non-agricultural employment:

Public and private transfers, including remittances

Other sources

$\begin{array}{ll}39 \% & 13 \% \\ 12 \% & 11 \% \\ 29 \% & 42 \% \\ 7 \% & 17 \% \\ 13 \% & 17 \%\end{array}$

Less poor rural households tend to be relatively less dependent on agriculture than poorer households, especially on agricultural wages, and more dependent on non-agricultural sources of income.

\section{There are important demographic changes in the rural labor force, including ethnicization, feminization, and aging.}

- Aging: In Mexico, the share of the rural labor force more than 41 years increased from $32 \%$ in 1992 to $41 \%$ in 2002. Access to land for young adults is made increasingly difficult by this process of aging, with limited land rental markets (Dirven, 2001).

- Feminization of the rural labor force: In Latin America as a whole, one observes a feminization of the rural population, of the rural labor force, of the agricultural population, and of rural non-agricultural employment (Katz, 2004). In Mexico, the share of women in the rural labor force increased from $22 \%$ in 1992 to $32 \%$ in 2002 . This rapidly 
- Fitting the Facts and Capitalizing on New Opportunities to Redesign Rural Development Programs in Latin America

rising participation of women is due to selective male migration, to strong expansion of labor intensive non-traditional exports, and to a fertility decline that frees women for participation in the labor market. Women suffer from lower wages on labor markets and disadvantages in access to land through inheritance and land reform programs (Deere and Leon, 2002). Their participation to non-agricultural employment is disproportionately in low productivity self-employment.

- Ethnicization of the rural population: Selective migration, with indigenous population attached to ancestral territories, leads to a rising share of indigenous people in the rural population.

\section{Inequalities are high and rising due to pervasive mechanisms of local reproduction of social inequalities in spite of growth, worsened by income shocks}

Local inequalities have proved to be highly resilient to time and to recent economic and social transformations (de Ferranti et al., 2004). Identification of the mechanisms through which local inequalities are reproduced is thus important. What are some of these mechanisms?

Under-investment by the poor in the education and health of their children is a powerful mechanism through which inequality is being reproduced. Breaking this pattern of inheritance is the main motivation for conditional cash transfer (CCT) programs such as Progresa in Mexico and Bolsa Escola in Brazil. By imposing school attendance and health visits as conditions for the transfers, CCT programs transform the transfer from an income into a price effect, gaining in impact on schooling and health per unit of transfer. In Mexico, Progresa erases the difference in school achievements between poor and non-poor in rural communities, helping break the inter-generational inheritance of low education and ill health.

Land distribution has remained largely unchanged, contradicting expectations of the rise of a powerful middle class of family farmers. This is in part because land and credit markets are strongly wealth biased. Land is overpriced relative to its use value, and many of the benefits from land ownership that is capitalized into land values relate to privileges of wealth (wealth shelter, social prestige, tax shelter). As a 
result, land is overpriced for poor borrowers, and only the wealthy can afford the full price of land. Credit markets are similarly wealth biased due to collateral requirements to face up to asymmetrical information between lenders and borrowers. As a consequence, short of financial institutions that substitute social collateral for wealth in borrowing, the poor tend to be shut out of financial markets, reproducing inequalities. Micro-finance institutions have made important headways in breaking this deadlock, but have to this stage not been effective in reaching small farmers.

Land rental markets are atrophied and socially segmented due to uncertain property rights and weak enforcement of rights. The consequence is that land tends to circulate within circles of confidence defined by kinship and class positions (Macours, de Janvry, and Sadoulet, 2004). Poor borrowers tend to be excluded from access to land put up for rental by large owners, reproducing local inequalities.

Finally, the reproduction of social inequalities is importantly achieved through local political economy processes (Finan, 2004). Class positions strongly affect choices in the allocation of public budgets. Clientelism and high local inequalities reproduce social exclusion and the overall regressivity of public expenditure programs.

We conclude this review of quantitative changes in poverty and social development by observing that gains in social development have not been matched by gains in productive development. There has been progress in social indicators, but little progress in income status. Aggregate growth has either been insufficient, or has been of a type unable to reduce poverty in rural areas. New approaches to rural development need address this lag between income and social progress.

\section{Emergence of new opportunities}

We identify six new opportunities to define an alternative approach to rural poverty reduction. They consist in globalization and market integration, increasing economic integration between rural and urban areas, progress in decentralization of governance, expansion of civil society organizations in rural areas, increasing demands for environmental services, and localized success stories with a territorial base. 
- Fitting the Facts and Capitalizing on New Opportunities to Redesign Rural Development Programs in Latin America

\section{Globalization and international market integration have led to:}

\subsection{A serious profitability crisis for small holders in traditional agriculture}

This profitability crisis in staple food crops is due to falling international prices (OECD protectionism), worsening domestic terms of trade (greater protection of industry than agriculture), low productivity growth in smallholder agriculture relative to the price decline, and sometimes declining yields due to environmental degradation (e.g., Bolivia). Government subsidies often protect the commercial sector (e.g., producer support per unit of gross farm output in Mexico is equal to $20 \%$, the same as in the US (The Economist, 2004)). However, these subsidies (such as Alianza Para el Campo) hardly reach small farmers like ejidatarios. In Mexico, the real price of crops produced by small farmers fell by $-4.8 \%$ /year between 1988 and 2002 (National Accounts).

An indictor of the profitability crisis in agriculture, compounded by laborsaving technological change, is the fall in real wages in agriculture. In Mexico, real wages in agriculture fell at the annual rate of $3.9 \%$ between 1988 and 2001 (National Accounts). In Brazil, real wages for permanent agricultural workers in agriculture declined by $40 \%$ between 1977 and 1997. For temporary workers in agriculture, the decline was $33 \%$ (FGVEstatisticas Agricolas).

\subsection{Opportunities offered by the "new agriculture"}

Urbanization and increasing integration in international markets open new opportunities to increase farm incomes on a limited land basis, which characterizes the rural poor. This is in meeting demands for high value crops such as vegetables, fruits, and animal products; quality foods required by urban distribution channels and exports (health standards, organic foods), standardized delivery in contracts with supermarkets, demands of agro-industry for non-traditional exports, labeling and certification of origin, post-harvest value added in commodity chains, etc. There are many dispersed success stories of small holders catering to non-traditional exports (Quatro Pinos in Guatemala), delivering to supermarkets (melons in Brazil, ejidos through Jacobs Farms in Baja California), and contracting with agro-industry (see Schejtman, 1998), 
indicating that the opportunities offered by the new agriculture, as an escape from the profitability crisis in traditional agriculture, can indeed be seized by small farmers. Capturing these opportunities requires, however, strong institutional support to achieve competitiveness and scale in delivery, which is not easy to achieve for smallholders.

\subsection{The industrialization of many rural areas}

There has been an extraordinarily rapid increase in the importance of non-agricultural employment and incomes for rural areas. Dirven (2004) estimates that $39 \%$ of the rural labor force is currently employed in non-agricultural activities, of which $2 \%$ are in mining, $21 \%$ in manufacturing, and $77 \%$ in services $(25 \%$ in trade, hotels, and restaurants; $11 \%$ in construction). Demand for services can be driven by incomes from agriculture, or from manufacturing and tourism. Manufacturing is also linked to agriculture or to decentralized industrial activities. Not all nonagricultural activities offer pathways from poverty. Self-employment and informal sector employment are often low productivity activities that help survival, and contribute important safety nets (additional to subsistence agriculture and agricultural wage employment), but with remunerations that perpetuate poverty. These are sectors where women and ethnic populations tend to be over-represented. Access to high productivity non-agricultural employment is fundamentally dependent on location, education, and younger age (Reardon, Berdegué, and Escobar, 2001).

\section{Rural areas are increasingly integrated economically with urban areas.}

Increasing integration between rural and urban markets is reflected in convergence between rural and urban wages. In Mexico, the rural/urban wage ratio rose from $28 \%$ in 1992 to $40 \%$ in 2002 (World Bank-Mexico, 2004). This wage convergence, that benefits more the educated and the higher income areas, has been an important factor in the observed rising inequality during the period.

As seen in Figure 1, proximity to urban areas is important for employment growth in manufacturing and (to a lesser extent) services. Rural and semi-urban municipalities with the highest growth in employment in manufacturing and services are closest to major employment clusters. Growth of employment in services is more auton- 
omous from distance to employment clusters as they also respond to agricultural potential and to the expenditure of remittances incomes in the municipality (Araujo, de Janvry, and Sadoulet, 2004). Half of the rural and semi-urban municipalities in Mexico benefit from this proximity effect for manufacturing employment, and $70 \%$ for services. Bringing rural areas "closer" to urban employment centers is thus a key source of growth in rural non-agricultural employment.
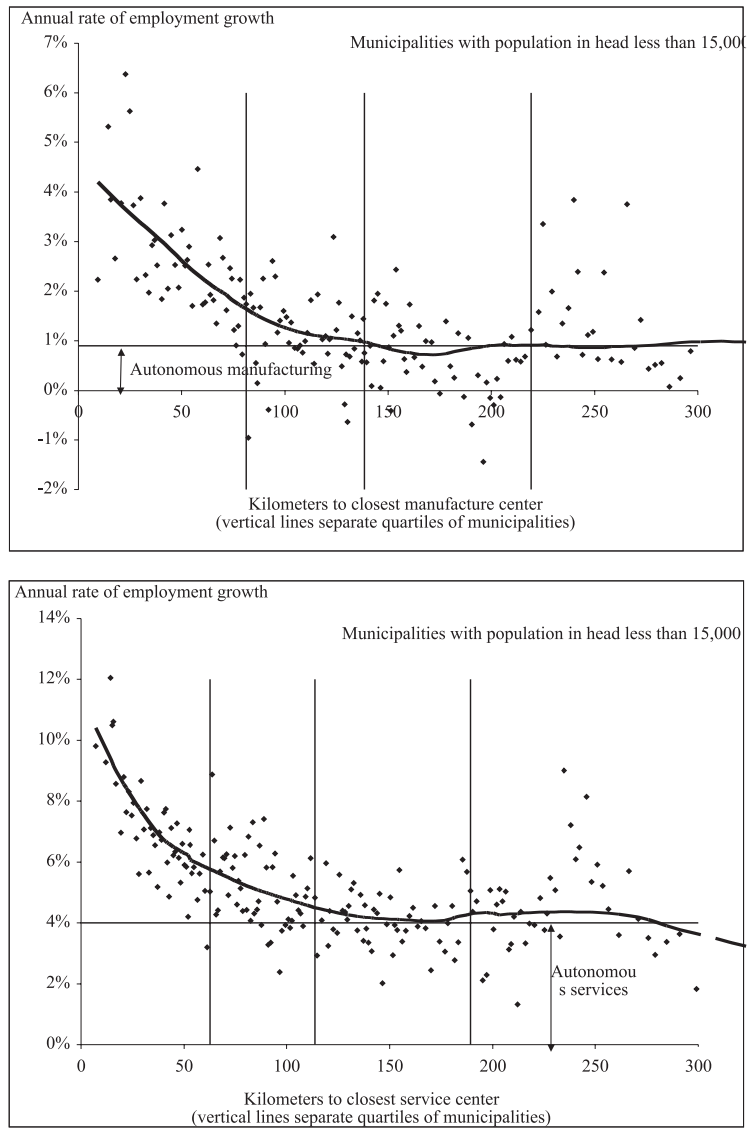

Figure 1. Annual rate of employment growth in manufacturing and services in rural and semi-urban municipalities by distance to an employment center in Mexico, 1990-2000

(Each point represents 10 municipalities. Source: Araujo, de Janvry, and Sadoulet, 2004) 
As can be seen in Figure 2, employment in manufacturing and services in rural areas is in turn associated with lower poverty as measured by the municipal marginality index. These empirical regularities suggest that a joint rural-urban territorial approach to poverty reduction that brings rural areas "closer" to urban employment centers offers opportunities for a new approach to rural development.
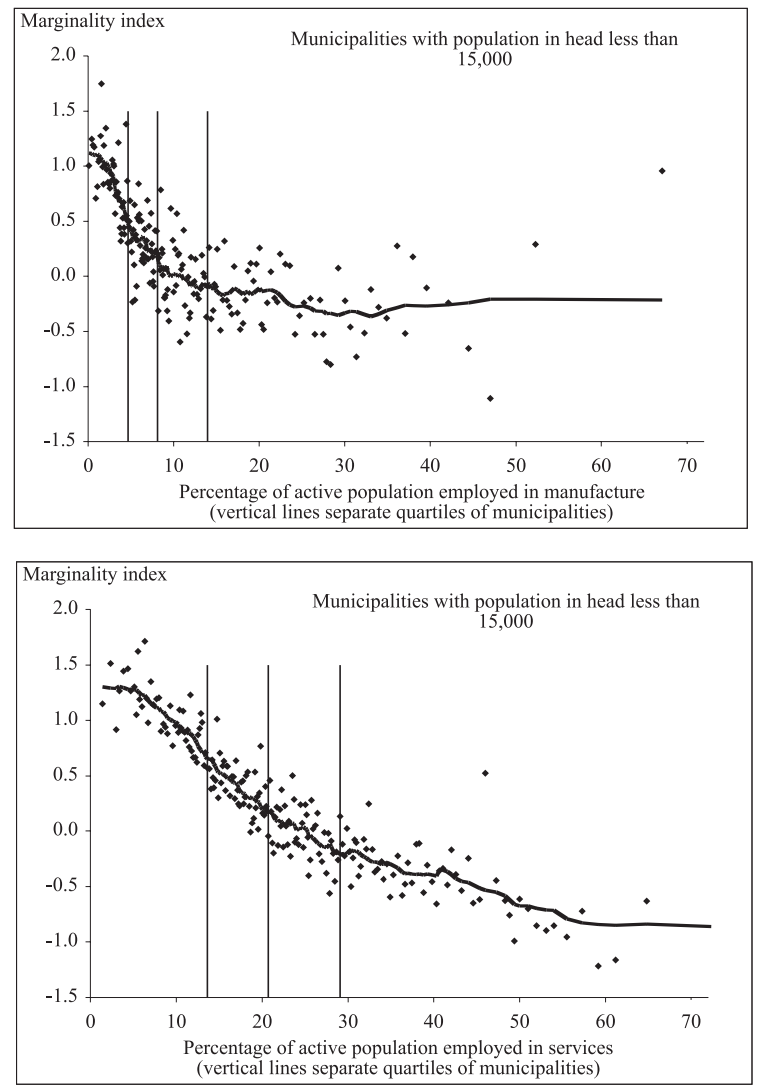

Figure 2. Rural non-farm employment and poverty levels in rural and semi-urban municipalities, Mexico 2000

(Each point represents 10 municipalities. Source: Araujo, de Janvry, and Sadoulet, 2004)

2. There has been much progress toward decentralization of governance at the municipal level

As a consequence of the strategy of industrialization by import substitution used throughout Latin America from the 1950s to the mid- 
Fitting the Facts and Capitalizing on New Opportunities to Redesign Rural Development Programs in Latin America

1980s, economic development has typically been highly centralized in a few mega-cities and a sector of large enterprises, leaving entire regions and productive sectors at the margin of the development dynamics. In the wake of limited success of structural adjustment policies with local economic and social development, strong demands for changes in this development pattern have emerged. Local elected officials and local representatives of civil and private sector organizations are demanding greater roles for local governments in not only social but also economic affairs. This has led to extensive decentralization in most countries of Latin America toward states and municipalities. Local social development has generally benefited, but economic gains in employment and investment opportunities have lagged relative to social development. The regional level of decentralization is still generally missing in this process.

Most Latin American countries have increased revenue sharing with municipalities (Brazil, Colombia, Mexico, Chile, Bolivia, Guatemala) or with provinces (Argentina) and states (Venezuela). In many cases, responsibility for primary education, health, water supply, local infrastructure, and security have been transferred to municipalities. Decentralization has, however, been mostly incomplete in that his has rarely been accompanied by fiscal decentralization and financial (borrowing) capacity for municipalities.

In Bolivia, extensive decentralization in 1994 made the municipality the basic unit of governance. The share of national fiscal revenues transferred from the central to municipal governments increased from $10 \%$ to $20 \%$ on a per capita basis. Decentralization led to a change in municipal budget allocation, with sharp increases in projects in urban development, education, health, water management, communications, and water and sanitation. By contrast, projects related to income generation (energy, industry and tourism, transport, and agriculture) have either stagnated or regressed (Faguet, 1997). Decentralization was accompanied by greater representation, participation, and accountability. Changes introduced included direct election of mayors, introduction of vigilance committees set up to oversee municipal spending, recognition of legal status to organizations of small farmers and indigenous people, and reduction of urban bias through extension of municipal jurisdiction to suburban and rural areas in the municipality. 
In Colombia, direct election of mayors and transfers of revenues and responsibilities (oversight of health care, water, local roads, and primary education) to municipalities were introduced starting in 1983. This led to sharp improvements in educational and health coverage, with a decline in illiteracy and with health services coverage rising from 35\% in 1990 to $63 \%$ in 2001. Local tax revenues have also increased. Again, gains were mainly achieved in basic social services and small-scale infrastructure.

Results from the Bolivian and Colombian experiences are important in showing both the potential gains from decentralization at the municipal level in achieving greater efficiency in basic social services and smallscale infrastructure, and also the limits of decentralization in supportive investments for employment creation and income gains. For this, larger geographical units would be needed, bringing up the concept of region in support of economic projects.

\section{There has been much progress with local social capital formation,}

particularly the expansion civil society organizations

Civil society organizations (CSOs) have increased rapidly, leading to a "thickening of civil society" (Fox, 1996). This has been particularly remarkable in countries where the weight of state intervention had historically limited the role of CSOs (Mexico, Brazil), where indigenous movements have gained political representation (Ecuador, Bolivia), and where decentralization of governance has created incentives for greater local participation (Bolivia, Peru). Introduction of local development councils (Brazil, Mexico, Uruguay) and open town meetings (El Salvador, Honduras) with participation of CSOs has also been a strong incentive to reinforce these organizations. Demands for greater local level participation have been extended to the national level through second-order organizations that link community organizations to national organizations (Bebbington, 1996). These organizations build social capital that goes beyond interest groups and can identify broadly shared concerns among different groups, allowing them to focus on larger themes such as political participation and economic development.

This explosion in CSOs places strong demands for greater democratic participation on local governments and for greater coordination between local and national policies and programs. The challenge is to transform 
Fitting the Facts and Capitalizing on New Opportunities to Redesign Rural Development Programs in Latin America

this "organizational revolution" into an instrument to achieve not only political gains and gains in improved local social services, but also in economic gains and poverty reduction (Manuel Chiriboga, personal communication).

4. There are increasing demands for the provision of environmental services

Increasing social demands for environmental services in the face of extensive deforestation, mismanagement of watersheds, and pollution of water by chemicals from agriculture offer new opportunities for rural development. Missing markets for improved watershed management, delivery of higher quality water to cities and irrigation districts, reduced pollution from use of chemicals in agriculture, greater biodiversity conservation and carbon capture, and improved landscape management call for introduction of payments for environmental services. Most countries in the region have experimented with such schemes (FAO, 2004). They have reached large scale in Costa Rica, national-level pilot stage in Mexico, and are prevalent at the local level in numerous watersheds. PES allow resource owners to increase returns to investments in natural resources, transferring resources to rural areas in support of rural development initiatives. In Mexico, $80 \%$ of forests are in the ejido sector, and forest ejidos tend to harbor indigenous populations and the poorest among rural households. Environmental planning and management needed to deliver environmental services give an additional justification for pursuing a territorial approach to rural development. Regions as economic units will for this reason often correspond to watersheds and to ecologically homogenous territories.

5. Localized success stories exist, and they often have a territorial base, but they lack in scale to make a difference in the aggregate poverty figures

There are a number of success stories of rural development where rural populations have found employment without having to migrate to the metropolises and where rural poverty may have declined. In this case, economic growth is secured on a regional basis, including an important role for large employment centers. Poor people in rural areas find employment opportunities in a broad array of economic activities, including agriculture; industries and services linked to agriculture, and 
decentralized activities in manufacturing. Lessons need to be derived from these experiences with territorial rural development.

Case studies of territorial rural development are available that allow to identify dimensions of the initiative and some determinants of success. Each case has its specificity. Some of the more interesting documented cases are the following (see Table at end of text):

LEADER program in European Union.

Community Empowerment Program of the USDA in the United States.

Petrolina-Juazeiro in the San Francisco Valley (Brazil): Damiani (2002)

Cajamarca (Peru)

Central Highlands of Guatemala: Non-traditional exports and Cuatro Pinos Cooperative.

SEDESOL's Micro-regions strategy in Mexico.

Central Valley of Chile: Agro-exports.

These experiences of territorial development show that there are several elements in common, in particular: (1) the need to define the region over which the development project applies, (2) the institutional transformation of the region, (3) the productive transformation of the region, and (4) the social transformation of the region. We use these categories to discuss the dimensions of a territorial approach to rural development.

\section{Strategies for rural development from a territorial perspective}

Major changes in the industrial structure of European countries (Italian industrial districts, decentralization in Denmark, LEADER project in the European union) have shown success with a more territorial approach to development, with flexible small-medium enterprises and clusters of economic activity providing support to innovation and competitiveness (Piore and Sabel; Porter). The rural dimension of these strategies has been essential. Quality of context in giving value to locally held assets is also fundamental, shifting emphasis from the firm as the engine of development to support offered to entrepreneurship by the regional and local context where it operates. In what follows, we discuss how this territorial approach to rural development could help fit the facts with 
- Fitting the Facts and Capitalizing on New Opportunities to Redesign Rural Development Programs in Latin America

qualitative changes in rural poverty and the emerging opportunities for rural development we have reviewed.

MRAs tend to have a high poverty rate but low population density, hence a low share of the rural poor. Poverty is geographically concentrated. These regions need to be gradually de-populated and integrated with dynamic regions. Indigenous territories need special programs, as these areas will retain relatively more populations. Options for these regions consequently include:

- Migration toward FRA and cities: need prepare migrants by investing in social development.

- Concentrate populations locally (purely voluntarily) in CECs for the delivery of social services: Mexico's Micro-regions strategy.

- Link MRA to FRA and urban centers through the construction of integrated regions and economic corridors.

- Offer environmental services (forestry, watershed management, in-situ conservation, eco-tourism).

FRAs have a low poverty rate, but high population density. They typically contain most of the rural poor in a country. Based on lessons learned from the successful experiences reviewed of regional development in Europe, the USA, and Latin America, pursuing a territorial approach to rural development in FRA would imply putting into place the following five dimensions: functional definition of a region, institutional transformation of a region, productive transformation of a region, social transformation of a region, and procedures for implementation of a territorial approach.

\section{Dimension 1: Define regions}

Regions for a territorial approach to rural development can be defined in several ways. They can be classified in the four following types:

- Municipality for local governance. Municipalities can be effective for the provision of local public goods and services, but are generally too small for the management of many economic projects. However, large municipalities can serve as economic units for regional development. 
- Ad-hoc association of municipalities in pursuit of particular projects (e.g., watershed management, delivery of a public service).

- Regions as larger administrative units: sub-national governments at the state, department, or province level.

- Regions as functional economic units: natural economic unit with shared comparative advantage, diversified employment basin, or social capital unit. These regions can be defined functionally through organizations such as a development bank (Banco do Nordeste for agro-industrial development), a cooperative (non-traditional exports in Guatemala), or a processing centers (milk production systems in Peru and Brazil). Key to these regions is the links between rural areas and urban centers.

In what follows, we assume that there are three administrative levels for territorial development:

- National level and state level if federal nations.

- Regional level: sub-national administrative unit, coalition of municipalities, or functional economic unit.

- Local level: municipality.

\section{Dimension 2: Institutional transformation of the region}

Element 1: Strengthen and modernize the capacity of local governments

- Greater economic capacity: Fiscal and financial (debt capacity) decentralization.

- Improved administrative capacity and accountability.

- Capacity of delivering basic services with high quality and efficiency.

Element 2: Strengthen the capacity of local organizations (social capital)

Strengthen local civil society and private sector representative organizations.

Element 3: Build institutions to plan and formulate projects for regional and local development

- Put in place institutions for consultation, coordination, and cooperation among public, private, and civil society sectors, in particular regional and local development councils. 
- Fitting the Facts and Capitalizing on New Opportunities to Redesign Rural Development Programs in Latin America

- Capacity for regional strategic planning: conceptualization and operationalization of a strategic vision for the region, with broad participation of public, civil, and private sector agents (regional development agency). Definition of regional and local development projects.

- Capacity of local universities for innovations, training, and technical assistance.

- Regional institutions for promotion of the region (chambers of commerce and industry, labeling of products, quality certification, regional image building (branding house) and advertising)

- Coordination with national programs for infrastructure and promotion of competitiveness.

\section{Dimension 3: Productive transformation of the region}

Element 1: Regional projects for infrastructure and financial development (State-region contracts)

- Public investments in infrastructure, in particular to link the region to dynamic national and international markets. Industrial parks and other public investments in support of private investment.

- Development of local and regional financial institutions.

Element 2: Promote the competitiveness of the region and local entrepreneurs (Region-driven development projects)

- Investments in entrepreneurship training, technical assistance, and public business incubators.

- Subsidies to investments that generate local positive externalities (decentralization, clustering) through grants and/or tax exemptions.

- Support to investments in the region's comparative advantages:

> Promote the "new agriculture" (local production systems for high value crops and animal products (milk, cheese), quality, labeling, value added through processing, contracts with supermarkets and agroindustries, food safety for exports).

> Promote the non-agricultural rural economy: agriculture linkages, decentralization of manufacturing. New services (environmental services, tourism, eco-tourism, retirement), and economics of proximity (commuting, subcontracting). 
> Capitalize on transfers and remittances as sources of financing and investment (capitalization of local financial institutions).

\section{Dimension 4: Social transformation of the region}

Rural development programs (social and productive expenditures) in support of the social incorporation of the poor

- Improve the asset position of the rural poor:

Access to land: redistributive land reform and subsidies to land purchase.

Human capital formation: conditional cash transfer programs for education and health (Progresa in Mexico, Bolsa Escola in Brazil) Social capital formation: promote membership to organizations.

- Combat the reproduction and deepening of social inequalities to insure broad sharing of the benefits of local/regional development.

- Safety net programs to support risk-taking by the poor.

\section{Dimension 5: Implementation of territorial rural development as a national strategy: Accountability and learning}

- Auditing and impact analysis for accountability.

- Results-based management for participatory learning and improvement based on monitoring and just-in-time impact analysis.

- Securing continuity beyond the political cycle and initial leadership (Cajamarca, Cuatro Pinos Guatemala): importance of broad social participation in the region and national/international visibility beyond the regional level.

\section{Conclusions: Main initiatives to implement a territorial approach}

We have argued that current approaches to rural development tend to lag relative to objective changes in the nature of rural poverty and to emerging opportunities available to attack poverty. In support of this, we have reviewed recent changes in the quantitative and qualitative nature of rural poverty, and in the set of emerging opportunities, to define a 
poverty reduction strategy. Along with a number of other analysts (see references in text), this has led us to identify the following dimensions to an integral territorial approach to rural development.

\section{Recognize the heterogeneity of territorial conditions}

Heterogeneity of geographies, local institutions, and household asset positions implies the need for location specific solutions. We have in particular used the contrast between Marginal Rural Areas (MRA) and Favorable Rural Areas (FRA) based on quality of agro-ecology and degree of market connectedness. Within these regions, heterogeneity of asset positions across households also implies that there exists a multiplicity of pathways from poverty. Hence, a poverty reduction strategy needs to be a social construct for a specific territory and for specific categories of households. Blue prints such as the agriculture- and state-led integrated rural development model or the Green Revolution do not exist in this approach.

\section{Rural areas are more than agriculture and need to be organized into regional/local territories}

In this approach, MRA must not be considered in isolation from FRA, rural areas must not be considered in isolation from urban areas, and the rural poor must not be considered in isolation from the rural non-poor. Geographical and social integration is the name of the game. In this perspective:

\section{(1) Regions are a continuum between rural and urban areas}

For functional reasons, regions should be constructed as centered on secondary cities that act as important employment centers and sources of demand for non-tradable. For this purpose, investments in infrastructure, transport, and communications are essential to the approach. Rural areas must be brought closer in travel time and in social interactions to regional urban centers. Together, the urban center and its rural areas constitute an employment basin based on the activities that correspond to the region's comparative advantages. 


\section{(2) Regions are constructed to support economic projects}

Municipalities (localities) can be effective for the local delivery of social services and for small infrastructure projects. Regions, composed of a multiplicity of localities, are constructed to support economic projects that can bring employment and investment opportunities to the localities that compose it. These projects are defined as state-region contracts and supported by region-driven development (RDD) funds, analogous to the familiar community-driven development (CDD) projects at the municipality level. For these projects, regions need to be linked to dynamic markets for tradable in metropolises and in the international economy.

\section{(3) The construction of economic regions requires a set of new institutions}

To perform their economic functions, regions need to be endowed with institutions to plan, coordinate, and promote. Planning may require a regional development agency. Coordination may require regional and local development councils. And promotion may require regional and local chambers of commerce and specialized professional organizations.

\section{(4) Regional projects aim at the productive transformation of the region}

Projects have as a purpose to promote entrepreneurship and give access to funding for new investment. The main emerging opportunities available in support of regional development that we reviewed are:

- Investments in "new agriculture" for high value added activities (crops, fruits and vegetables, livestock, and fish) and access to new outlets (supermarkets, agro-industry, international demands for quality and healthy products). Profitable agricultural activities catering to dynamic markets will thus remain the engine of growth in a territorial approach to rural development, as they did under agriculture-based integrated rural development. For this, productivity gains in new agriculture are an essential dimension of the approach. This is indeed the case with some of the most successful territorial approaches to rural development: PetrolinaJuazeiro in Brazil, NTX in Guatemala, and agroexports in Chile.

- Investments in non-agricultural rural enterprises. These are either linked to agriculture, to tourism or a regional natural resource, or to 
Fitting the Facts and Capitalizing on New Opportunities to Redesign Rural Development Programs in Latin America

decentralized industry. In all cases, services derived from these drivers of growth provide the most important sources of non-agricultural employment.

- Investment of liquidity derived from remittances, made available to local entrepreneurs through community-based financial institutions. Trough privileged access to local information and social capital, these financial institutions can lend locally at an advantage relative to financial institutions from outside the locality.

- Investments in the provision of environmental services. PES schemes can provide important inflows of cash transfers toward rural areas. These payments can support not only improved management of resources, but also gains in the welfare of service providers, often among the region's poorest.

\section{(5) The multiplicity of activities in a region requires multi-sectoral projects}

Investments in support of rural development have typically focused on agriculture, with blue prints like the Green Revolution. A territorial approach requires instead demand-led and participatory approaches. That recognizes the heterogeneity of conditions, and integrates agriculture with activities beyond agriculture. Region-Driven Development funds can help finance these multi-sectoral initiatives.

\section{Rural poverty reduction requires specific interventions to help the poor gain access to the opportunities offered by regional growth}

These more classical aspects of rural development interventions focus on:

\section{(1) Improving the asset position of the rural poor}

This includes most specifically:

- Access to land through redistributive land reforms and subsidiesassisted market transactions.

- Improvement in skill (adults) and educational (children) levels, with conditional cash transfer programs an effective approach for the latter. - Organizations (social capital) for representation and service. 


\section{(2) Reducing market failures that affect the poor}

This includes notably lack of access to credit and insurance. This requires constructing institutions that can serve the rural poor under the specific conditions that characterize them: strong wealth constraints and high levels of risk aversion, but endowments in local knowledge and social capital that can serve for social collateral and mutual insurance.

(3) Securing the competitiveness of the poor on both labor and product markets

This requires not only reduction of markets failures, but links between poor and non-poor and organizations that can help the poor achieve bargaining power and scale in their relations with markets (supermarkets), agro-industry, and sources of contracts or employment.

\section{(4) Addressing the special problem of populations in MRAs}

Dispersed populations in marginal rural areas, often indigenous populations attached to ancestral territories, are difficult to service in public goods. Gradual relocation in Strategic Community Centers (Mexico) can be effective for the delivery of social services and small infrastructure. Preparing populations to migrate to FRAs and regional employment centers is part of the strategy. Linking FRAs to MRAs is essential for this and to secure competitiveness of economic activities in MRAs.

\section{Implementation}

Implementing an integral territorial approach to rural development requires political support and should be designed as a learning process.

\section{(1) Shift equilibrium using a big push approach}

A territorial approach will not work as an isolated experiment at a limited scale. This is well evidenced in successful case studies. It requires coordination with national and macro-policies. It also requires political support to mobilize sustained investments over time. And it requires investments to link rural and urban areas, regions with international markets, MAR with FAR, and to finance multi-sectoral projects. Dispersed NGO-type approaches will not be sufficient to unleash the potential of a territorial approach. Due to the importance of geographical spillover 
Fitting the Facts and Capitalizing on New Opportunities to Redesign Rural Development Programs in Latin America

effects, a coordinated big-push approach is needed to shift to a higherlevel regional equilibrium.

(2) Impact analysis must be done for accountability and for learning with results-based management

Audit is needed to secure efficient use of public and donor resources. For this purpose, standard process evaluation and impact analysis approaches need to be used. In addition, process evaluation and impact analysis should feed into results-based management methods, based on participation and feedbacks from lessons learned into redesign of approaches. This is not free. Resources need to be committed in support of making the approach into a learning process.

\section{References}

Abramovay, Ricardo. 1999. “A capital social dos territórios: Repensando o desenvolvimento rural”. Economics Department, University of Sao Paulo.

Abramovay, Ricardo. 2003. "Desafios para a gestão territorial do desenvolvimento sustentável no Brasil”. SOBER.

Akerlof, George. 1984. An Economic Theorist's Book of Tales. Cambridge University Press.

Araujo, Caridad, Alain de Janvry, and Elisabeth Sadoulet. 2004. "Spatial Patterns of Non-Agricultural Employment Growth in Rural Mexico during the 1990s”. University of California at Berkeley.

Bebbington, Anthony. 1996. “Organizations and Intensifications: Campesino Federations, Rural Livelihoods, and Agricultural Technology in the Andes and Amazonia”. World Development 24(7): 1161-77.

Damiani, Octavio. 2002. "Diversification of agriculture and poverty reduction: Effects on small farmers and rural wage workers of the introduction of non-traditional high-value crops in Northeast Brazil”. Ph.D. dissertation, MIT.

Deere, Carmen Diana, and Magdalena León. 2001. Empowering Women: Land and Property Rights in Latin America. University of Pittsburg Press. 
de Ferranti, David, Guillermo Perry, Francisco Ferreira, and Michael Walton. 2004. Inequality in Latin America and the Caribbean: Breaking with History? Washington D.C.: The World Bank.

de Janvry, Alain, and Elisabeth Sadoulet. 2000. "Growth, Poverty, and Inequality in Latin America: A Causal Analysis, 1970-94”. The Review of Income and Wealth 46(3): 267-288.

de Janvry, Alain, and Elisabeth Sadoulet. 2000. "Rural Poverty in Latin America: Determinants and Exit Paths”. Food Policy 25: 389-409.

Dirven, Martine. 2001. "El Mercado de tierras y la necesidad de rejuvenecimiento del campo en América Latina”. Santiago: CEPAL.

Dirven, Martine. 2004. "Rural Non-Farm Employment and Rural Diversity: Some Latin American Evidences”. CEPAL Review, forthcoming.

Durston, John, E. Espindola, A. Leon, B. David, S. Parada, and M. Dirven. 2000. "Empleo rural no-agricola y pobreza en América Latina: Tendencias recientes”. Santiago: ECLAC.

Echeverri, Rafael. 2000. “Nueva Ruralidad”. San José, Costa Rica: IICA.

Echeverría, Ruben. 2004. "Banco Interamericano de Desarrollo: Estrategia de Desarrollo Rural”. Washington D.C.: IDB.

Economist (The). 2004. “Indicators: Agricultural Subsidies”. July 1.

Elbers, Chris, Peter Lanjouw, Johan Mistiaen, Berk Özler, and Ken Simler. 2004. "On the Unequal Inequality of Poor Communities". DECRG, The World Bank.

Faguet, Jean-Paul. 1997. “Decentralization and Local Government Performance”. London School of Economics.

FAO. 2004. Payment Schemes for Environmental Services in Watersheds. Land and Water Discussion Paper No. 3, Rome.

Finan, Frederico. 2004. "Political Patronage and Local Development: A Brazilian Case Study”. ARE, UC Berkeley.

Fox, Jonathan. 1996. "How Does Civil Society Thicken? The Political Construction of Social Capital in Rural Mexico". World Development 24(6): 1089-1103. 
Katz, Elizabeth. 2004. "La evolución del papel de las mujeres en las economías rurales latinoamericanas”. In FAO, Temas actuales y emergentes para el análisis económico y la investigación de políticas. Rome.

Llorens, Juan Luis, Francisco Albuquerque, and Jaime del Castillo. 2002. "Estudio de casos de desarrollo económico local en América Latina". Washington D.C.: IDB.

Macours, Karen. 2004. "Insecurity of Property Rights and Matching in the Tenancy Market”. ARE, UC Berkeley.

Mansuri, G., and V. Rao. 2004. "Community Based (and Driven) Development: A Review”. World Bank Research Observer, forthcoming.

Raine, Martin, et al. 2004. "Drivers of Sustainable Rural Growth \& Poverty Reduction in Central America." The World Bank.

Reardon, Thomas, Julio Berdegué, and Germán Escobar. 2001. "Rural Nonfarm Employment and Incomes in Latin America: Overview and Policy Implications”. World Development 29(3): 395-409.

Rojas and Frank. 2004. "Assessment of the Impact of Decentralization: The Case of Colombia, 1992-2001".

Schejtman, Alejandro. 1998. "Agroindustria y pequeña agricultura: Experiencias y opciones de transformación”. In CEPAL/GTZ/FAO, Agroindustria y pequeña agricultura: vínculos, potencialidades y oportunidades comerciales. UN: Santiago, Chile.

Schejtman, Alejandro, and Julio Berdegué. 2003. “Desarrollo Territorial Rural”. RIMISP.

Scholl, Lynn. 2003. "The role of institutions in regional economic development: Case studies from Latin America”. Goldman School of Public Policy, UC Berkeley.

Wodon, Quentin. 2000. "Poverty and Policy in Latin America and the Caribbean”. LCSPP, The World Bank.

World Bank-Mexico. 2004. "Poverty in Mexico: Conditions, Trends, and Government Strategy”. The World Bank Mexico Office. 


\begin{tabular}{|c|c|c|c|c|c|c|c|c|c|}
\hline 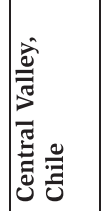 & 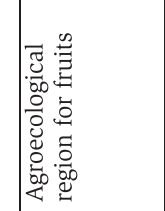 & 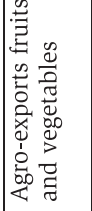 & $\stackrel{0}{z}$ & 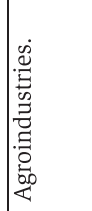 & 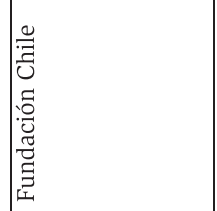 & 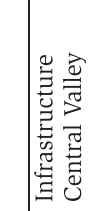 & 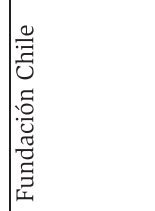 & $\stackrel{\circ}{z}$ & 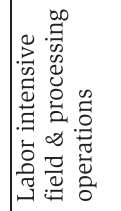 \\
\hline 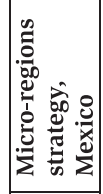 & 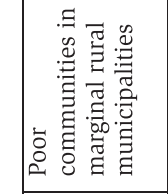 & 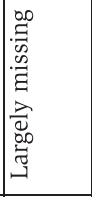 & & 宽 & 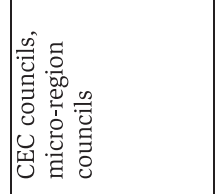 & 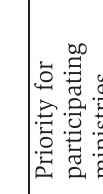 & 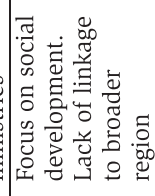 & 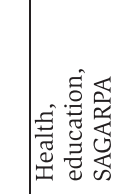 & ă \\
\hline 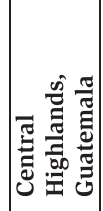 & 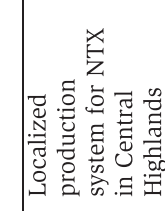 & 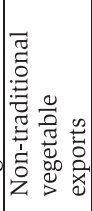 & 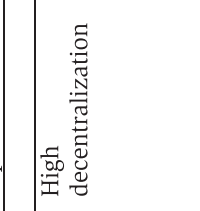 & 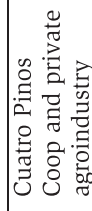 & & & 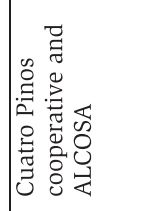 & 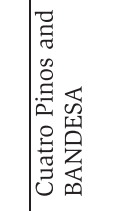 & 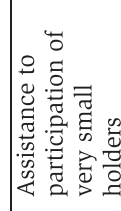 \\
\hline 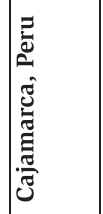 & 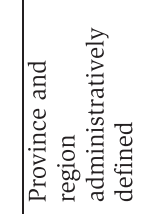 & 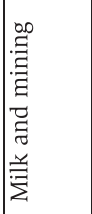 & 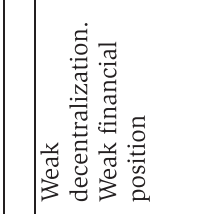 & 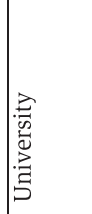 & 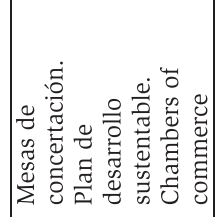 & 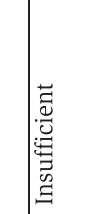 & 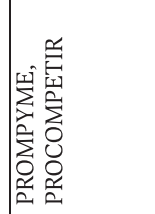 & 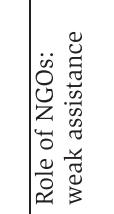 & $\stackrel{\circ}{z}$ \\
\hline 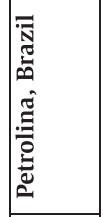 & 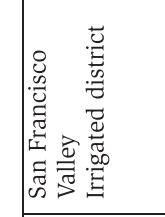 & 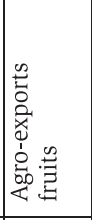 & 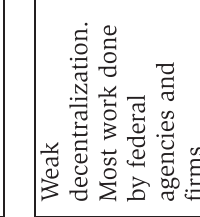 & 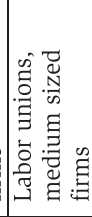 & 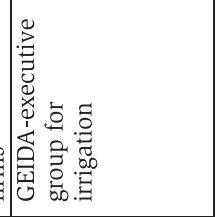 & 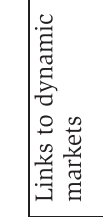 & 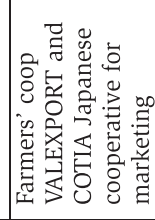 & 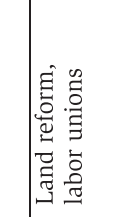 & 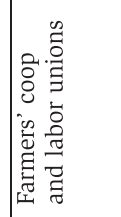 \\
\hline 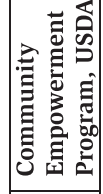 & 苞 & 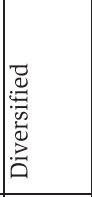 & 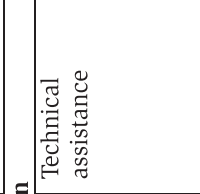 & 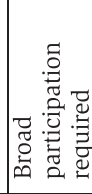 & 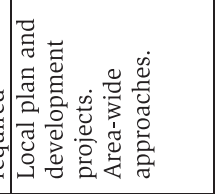 & 竞 & 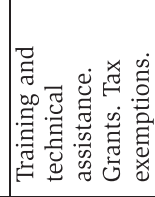 & $\stackrel{\circ}{z}$ & 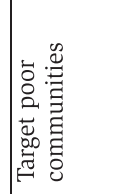 \\
\hline 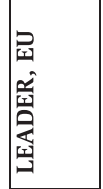 & 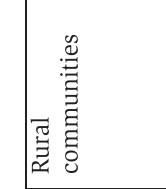 & 苞 & 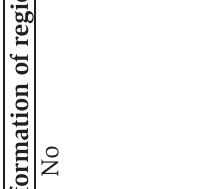 & 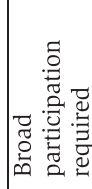 & 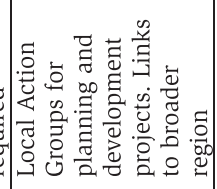 & 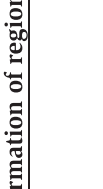 & 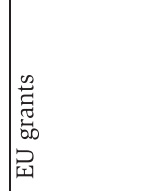 & 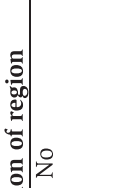 & z \\
\hline & صี & 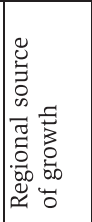 & 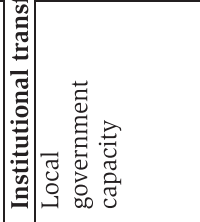 & 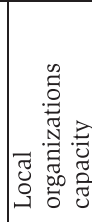 & 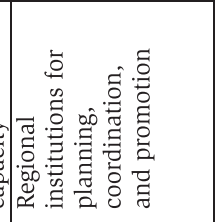 & 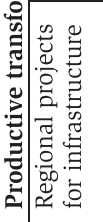 & 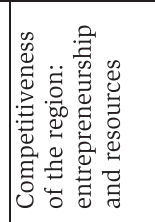 & 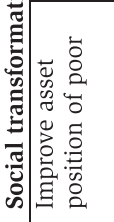 & 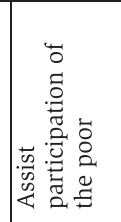 \\
\hline
\end{tabular}

